\title{
Entrapment of the Sural Nerve on Gastrocnemius Muscle: Histological Analysis
}

\author{
Compresión del Nervio Sural en el Músculo Gastrocnemio: Análisis Histológico
}

Rafael C. De-Paula; Bruno Felix; Ewerton C. Bezerra; Mauro R. Rodrigues; Rodrigo M. P. Fernandes \& Marcio A. Babinski

DE-PAULA, R. C.; FELIX, B.; BEZERRA, E. C.; RODRIGUES, M. R.; FERNANDES, R. M. P. \& BABINSKI, M. A. Entrapment of the sural nerve on gastrocnemius muscle: histological analysis. Int. J. Morphol., 29(3):806-809, 2011.

SUMMARY: Anatomical variations in the formation of the sural nerve are common, although the topographical localization of this nerve is constant. In this report, we describe the histological analysis of anomalous course of the medial sural cutaneous nerve which descended through the gastrocnemius via a tunnel formed within the muscle and fascia. This anatomical curiosity are clinically important when evaluating sensory axonal loss in distal axonal neuropathies since sural nerve mononeuropathy is less likely to occur.

KEY WORDS: Sural nerve; Gastrocnemius muscle; Variations; Histology.

\section{INTRODUCTION}

The sural nerve (SN) is formed by the union of the medial sural cutaneous nerve (MSCN) and the lateral sural cutaneous nerve (LSCN) which are branches of tibial and common fibular nerves respectively (Mahakkanukrauh \& Chomsung, 2002; Pimentel et al., 2005) In 20 to $32.2 \%$ of the cases the SN is formed by a direct continuation of the MSCN, without fibular nerve branches (Mahakkanukrauh \& Chomsung; Ortigüela et al., 1987).

The site of union of the MSCN and LSCN to form the sural nerve is highly variable. The union occurs in $12 \%$ of the cases in the popliteal fossa, and in $84 \%$ it occurs in the lower third of the leg (Coert \& Dellon, 1994). After the joint the $\mathrm{SN}$ crosses the deep fascia between the heads of the gastrocnemius to run vertically downwards, lateral to the small saphenous vein and lateral to calcaneal tendon (Sankar et al., 1009; Testut \& Jacob, 1994; George \& Nayak, 2007).

Several authors indicated that the sural nerve may pierce the medial head of the gastrocnemius muscle before following its path (Bergman et al., 1988; Testut \& Jacob; Mahakkanukrauh \& Chomsung; Ortigüela et al.). The transmuscular path corresponded to a frequency of $10 \%$ of the individuals meaning that this variation is important at the time of surgery and diagnostics in routine clinical work.
Generally the SN was described as being only sensory, responsible for the sensitive enervation of the foot's margin and of the fourth and fifth toes and also providing branches to the side of ankle and heel (Testut \& Jacob; Pimentel et al.).

Generally the SN was described as only sensory, responsible for the sensitive enervation of the border margin of the foot and of the fourth and fifth toes; and also provides branches to the lateral side of ankle and heel (Testut \& Jacob; Pimentel et al.).

Nevertheless, some authors have suggested that the $\mathrm{SN}$ is not only sensorial, and in a few cases has motor fibers that give to abductor digiti minimi of the foot and possibly other intrinsic foot muscles and the gastrocnemius muscle when it pierces the medial head as previously reported by our group (Pimentel et al.,; Haupts \& Amoiridis, 2007; Amoiridis et al., 1997; George \& Nayak). The motor fibers in $\mathrm{SN}$ are present in $6.2 \%$ of individuals (Haupts \& Amoiridis; Amoiridis et al., 1997).

The present study analyzes by histological techniques, whether the SN promotes a motor innervation of gastrocnemius muscle when this nerve crosses the medial head of this muscle. 


\section{MATERIAL AND METHOD}

The leg of a male human cadaver was preserved and fixed in $10 \%$ buffered formalin, dissected and the popliteal fossa and sural compartment were explored. The SN showed a variation course, entrapment with the medial head of the gastrocnemius muscle was also observed. Pieces of the muscle tunnel (intramuscular course) were removed carefully and analyzed by histological techniques (Fig.1).

Tissue samples were subjected to routine histological processing and embedded in paraffin. The paraffin blocks were set parallel to the tube long axis, and approximately 5$\mu \mathrm{m}$ thick serial transverse sections were obtained from the central portion of each tube and were stained with hematoxylin-eosin and Masson's Trichrome.

\section{RESULTS}

The SN was dissected following its trajectory along the popliteal fossa and downward in the leg and an anatomical variation where the $\mathrm{SN}$ appears, was found in an unusual path that pierces the medial head of the gastrocnemius muscle and continues after reaching the leg in the usual manner, on the side of the small saphenous vein and laterally to calcaneal tendon (Achilles).

Relationship between the nerve and muscle tissue in the transmuscular course were analyzed by microscopy. Blocks were cut in an intramuscular course with a transverse cut and showed that this muscle tunnel is only a passage path as no branches (motor fibers) were found from the SN to muscle tissue. The nerve runs on the side of the artery and existing veins in the distal portion, and continues downward in the leg (Fig. 2.).

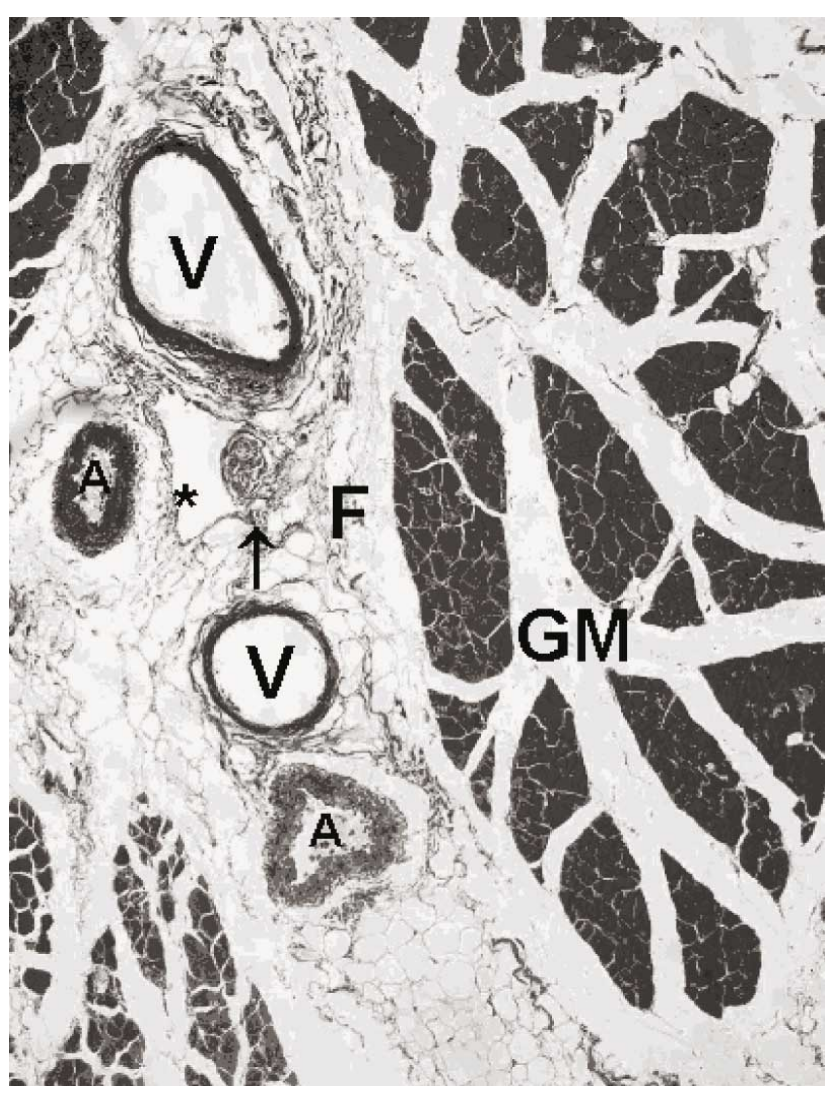

Fig. 2. Photomicrograph showing the histological arrangement of the intramuscular relationship of the medial sural cutaneous nerve (arrow). V. Muscular veins; A. Muscular arteries; GM. Gastrocnemius muscle; F-Crural fascia. Masson’s Trichrome. 40X
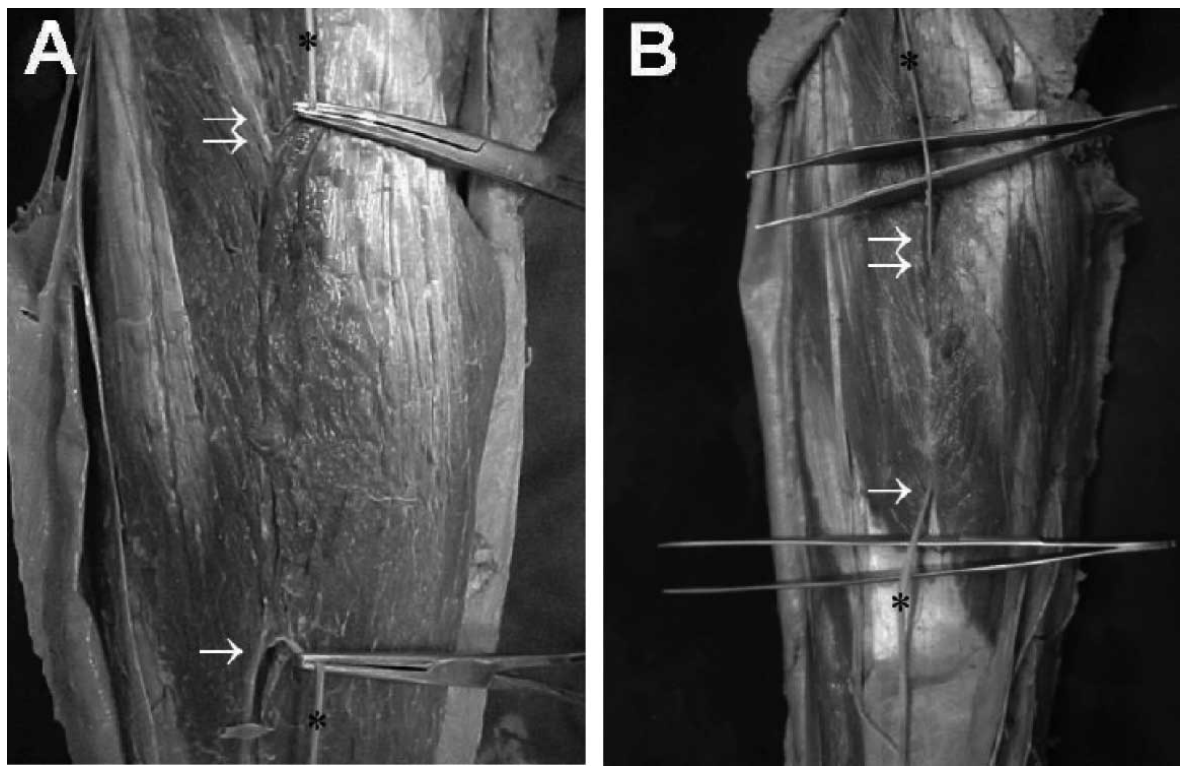

Fig. 1. A. Photograph of the left leg showing the intramuscular course of the medial sural cutaneous nerve (asterisks) piercing the gastrocnemius muscle (double arrow). The single arrow shows the point of exit. B. Subfascial course of the sural nerve (Pimentel et al., 2005). 


\section{DISCUSSION}

The $\mathrm{SN}$ is clinically relevant principally because it is frequently used in nerve transplants, and it is widely used for both diagnosis (biopsy and nerve conduction velocity studies) and therapeutic purposes (nerve grafting) (George \& Nayak). It is the main nerve used to evaluate sensory axonal loss in distal axonal neuropathies, primarily because sural nerve mononeuropathy is a very rare event (Seror, 2002).

In cases where the sural nerve is compressed because of a lower limb injury, or when an anatomical variation of entrapment of the SN occurs in the gastrocnemius muscle, or in the deep fascia, this event could be associated with neuropathies of this nerve (Pimentel et al.).

Seror reported a case of three males who used new ski boots and suffered neuropathies. The patients showed hypoesthesia in the external border of the right foot indicating sural nerve involvement.

For Coert \& Dellon, in a patient where the nerve pierced the deep fascia, a compressive force in the nerve could be exerted by the fascia during the knee extension and a biopsy of a SN could result in misdiagnosis of axonal polineuropathy (Coert \& Dellon).

Bryan et al. (1999) described a case of a patient who suffered an injury in the right leg on the medial gastrocnemius muscle. The patient reported pain in the lower leg and foot, in the area enervated by the SN, pain was accentuated by plantar flexion. Surgical exploration found that the nerve was pierced in the scar tissue beneath the deep fascia at the level of the gastrocnemius muscle.

Several authors have reported an anomalous enervation of abductor digiti minimi of the foot via SN (Haupts \& Amoiridis; Amoiridis et al.). However, the works do not associate the presence of this anomalous enervation with the presence of the transmuscular course of the SN.

Goerge Nayak have suggested that the muscular course of the SN could be associated with a motor enervation of the gastrocnemius muscle. In this work a case of this anatomical variation was reported. However, no branches were found arising from the SN to muscle tissue in the muscular path. Greater numbers of legs with this anatomical variation are needed for analysis with histological techniques as were carried out in this study, to determine if the SN with its rare motor branches promotes enervation of the gastrocnemius muscle in this path.

Anatomically and clinically this variation is very important and requires attention from physicians as well as other healthcare professionals.

DE-PAUlA, R. C.; FELIX, B.; BEZERRA, E. C.; RODRIGUES, M. R.; FERNANDES, R. M. P. \& BABINSKI, M. A. Compresión del nervio sural en el músculo gastrocnemio: análisis histológico. Int. J. Morphol., 29(3):806-809, 2011.

RESUMEN: Las variaciones anatómicas en la formación del nervio sural son comunes, aunque la localización topográfica de este nervio es constante. En este reporte se describe el análisis histológico del nervio cutáneo sural medial de curso anómalo, que descendió a través de los músculos gastrognemios en un túnel formado en el músculo y la fascia. Esta curiosidad anatómica es de importancia clínica cuando se evalúa la pérdida sensitiva distal en neuropatías axonales, desde mononeuropatía del nervio sural a otras de menor frecuencia.

PALABRAS CLAVE: Nervio sural; Músculo gastrocnemio; Variaciones; Histología.

\section{REFERENCES}

Amoiridis, G.; Schöls, L.; Ameridis, N. \& Przuntek, H. Motor fibers in the sural nerve of humans. Neurobiology, 49(6):1725-8, 1997.

Bergman, R. A; Thompson, S. A.; Afifi, A. K. \& Saadeh, F. A. Compendium of human anatomic variation: Catalog, Atlas and World Literature. Baltimore and Monich, Urban \& Schwarzenberg, 1988.
Bryan, M. B. 3rd; Lutz, G. E. \& O’Brien, S. J. Sural nerve entrapment after injury to the gastrocnemius: a case report. Arch. Phys. Med. Rehabil., 80(5):6046, 1999.

Coert, J. H. \& Dellon, A. L. Clinical implications of the surgical anatomy of the sural nerve. Plast. Reconstr. Surg., 94(6):850-5, 1994. 
DE-PAULA, R. C.; FELIX, B.; BEZERRA, E. C.; RODRIGUES, M. R.; FERNANDES, R. M. P. \& BABINSKI, M. A. Entrapment of the sural nerve on gastrocnemius muscle: histological analysis. Int. J. Morphol., 29(3):806-809, 2011.

George, B. \& Nayak, S. Sural nerve entrapment in gastrocnemius muscle - A case report. Neuroanatomy, 6:41-2, 2007.

Haupts, M. R. \& Amoiridis, G. The sural nerve is not always a pure sensory nerve. Muscle Nerve, 35(6):812, 2007.

Mahakkanukrauh, P. \& Chomsung, R. Anatomical variations of the sural nerve. Clin. Anat., 15(4):263-6, 2002.

Ortigüela, M. E.; Wood, M. B. \& Cahill, D. R. Anatomy of the sural nerve complex. J. Hand Surg. Am., 12(6):111923, 1987.

Pimentel, M. L.; Fernandes, R. M. P. \& Babinski, M. A. Anomalous course of the medial sural cutaneous nerve and its clinical implications. Braz. J. Morphol. Sci., 22:179- 82, 2005

Sankar, B.; Bhanu, S.; Susan, P. J. \& Gajendra, K. Variant formation of sural nerve and its distribution at the dorsum of the foot. Int. J. Anat. Variat., 1:33-4, 2009.

Seror, P. Sural nerve lesions: a report of 20 cases. Am. J. Phys. Med. Rehabil., 81(11):876-80, 2002.

Testut, L. \& Jacob, O. Tratado de Anatomia topográfica con aplicaciones Médico-quirúrgicas. $6^{\mathrm{a}}$ edn. Barcelona, Salvat, 1944.
Correspondence to:

Prof. Dr. Marcio Antonio Babinski

Departamento de Morfologia, Instituto de Biomédico

Universidade Federal Fluminense (UFF)

Rua Ernani Mello, 101, São Domingos

CEP 24.210-150

Niterói, RJ

BRAZIL

Fax: (55) (21) 2629-2336.

Email: mababinski@gmail.com

Received: 01-01-2011

Accepted: 23-05-2011 